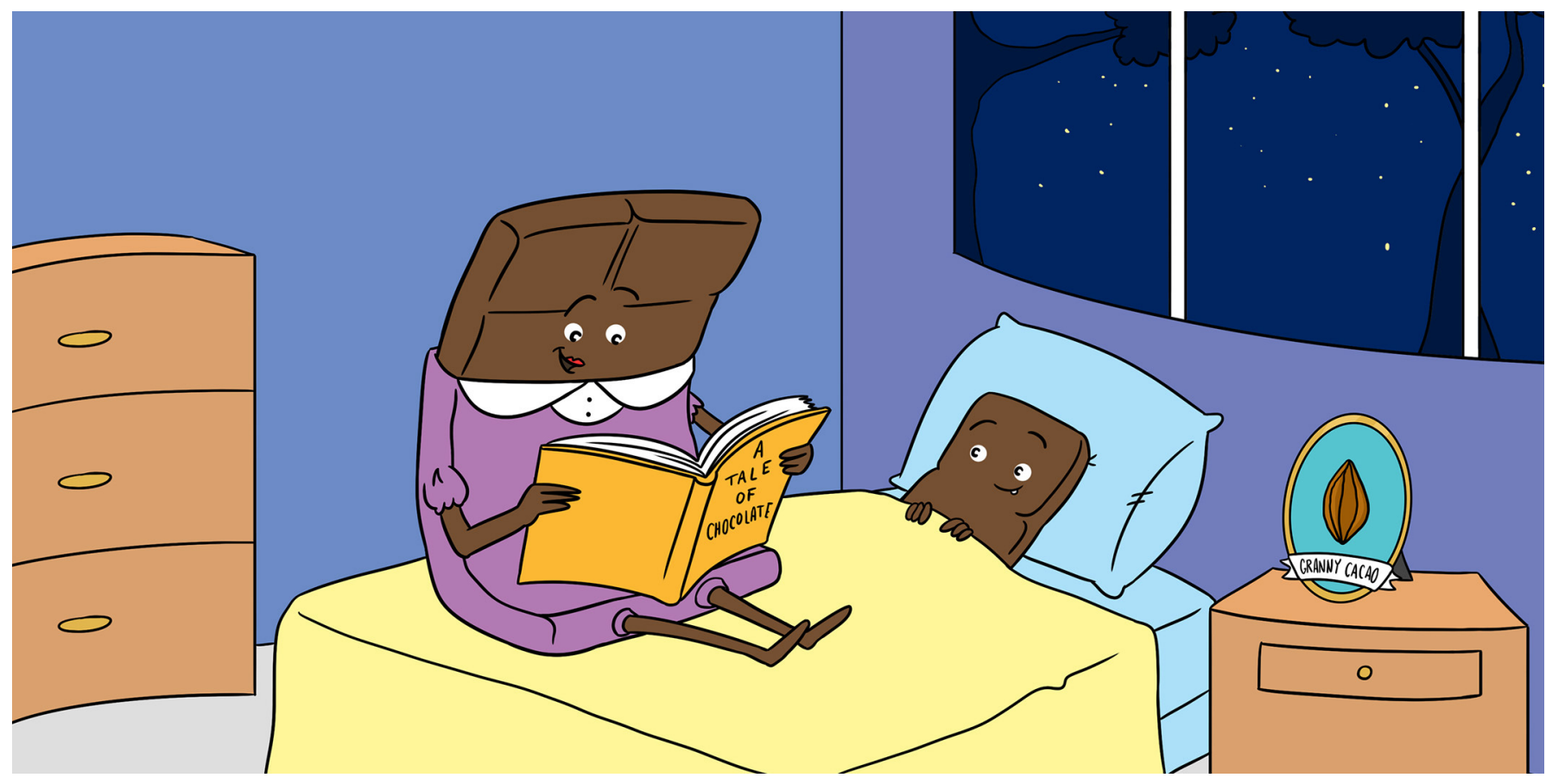

\title{
A DELICIOUS STORY MADE OF CHOCOLATE
}

Caren Rodriguez-Medina ${ }^{1^{*}}$, Sebastian Escobar ${ }^{1}$, Alejandro Caro-Quintero ${ }^{2}$ and Roxana Yockteng ${ }^{2,3}$

${ }^{1}$ Corporación Colombiana de Investigación Agropecuaria-Agrosavia, Centro de Investigación Palmira, Palmira, Colombia

${ }^{2}$ Corporación Colombiana de Investigación Agropecuaria-Agrosavia, Centro de Investigación Tibaitatá, Mosquera, Colombia ${ }^{3}$ Biodiversité-UMR-CNRS 7205, National Museum of Natural History, Paris, France

YOUNG REVIEWERS:

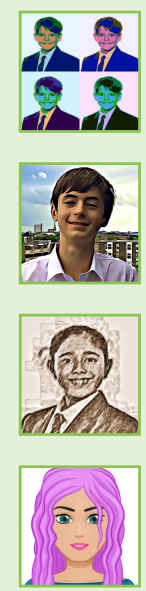

DANIEL

AGE: 12

OLI

AGE: 13

SHEENA

AGE: 12

SHIRIN

AGE: 14
Did you know that chocolate is obtained from beans extracted from the fruit of a tree called Theobroma cacao? The fruits are yellow or deep red pods that contain beans covered with a sweet-bitter pulp. Cacao originated in the Amazon region and, for this reason, South America has the highest genetic diversity of the species. The special flavor of each chocolate depends on genetics and the process of transforming cacao seeds into chocolate bars. Cacao cultivation has a fascinating story for which we have to travel through time. The story begins way back with ancient indigenous civilizations that consumed cacao as a drink, and for whom cacao beans were a symbol of power. After the Spanish colonization of the Americas, cacao pods were taken to Europe. In this article, we will learn about the history and importance of cacao for some civilizations, the genetic diversity of cacao species, and the transformation of cacao beans to chocolate. 


\section{FERMENTATION}

A process that results in chemical changes in cacao beans through the action of microbes, including yeast and bacteria.

\section{GENOTYPE}

Genetic makeup of any organism that gives its unique characteristics.

\section{WHERE DOES CHOCOLATE COME FROM?}

Chocolate is obtained from the transformation process of beans extracted from the fruit of a tree called Theobroma cacao. Cacao beans are removed from yellow or deep red fruit pods harvested from cacao trees and are transformed into chocolate through several processes, such as fermentation, drying, and roasting. The chocolate flavor is influenced by different factors: the cacao genotype, the growing conditions of the cacao trees, and how the beans are treated after harvest. Cacao originated in the Amazon region of South America which has the highest genetic diversity of the species. Cacao played an important role in the history of some pre-Hispanic indigenous civilizations and was taken to Europe by the Spaniards who came to the American continent.

\section{WAS CACAO IMPORTANT FOR ANCIENT CIVILIZATIONS?}

Theobroma cacao played an important role in the social and political organization of several pre-Hispanic indigenous civilizations from Central Mexico through Belize, Guatemala, El Salvador, Honduras, Nicaragua, and Northern Costa Rica, that used to live in the Mesoamerican region before the arrival of Spanish explorers. In pre-Hispanic Mesoamerica, cacao was a sign of wealth and power. Archaeological studies have found some interesting things about the consumption of chocolate in ancient societies. For instance, for the indigenous people of the Late Classic Maya Period, drinking chocolate was associated with important events, such as political alliances, marriage arrangements, and civic agreements between individuals [1]. Cacao beans also became a precious form of currency for commercial transactions. The evidence suggests that T. cacao was used in funeral rituals, to feed those who began their journey toward the afterlife. This hypothesis is supported by cacao seeds found in burial caves. In the case of the Aztec empire, drinking chocolate became a symbol of political power and social prestige contributing to the birth of the elites, a small group of people who held political and economic power [2].

\section{HOW DID CACAO ARRIVE IN EUROPE?}

The Spaniards who came to the American continent enslaved the people living there and demanded cacao beans as payment. Because cacao was a symbol of wealth and social status in the Mesoamerican indigenous civilizations, the Spaniards were attracted to the most cacao-producing regions. After the arrival of the Spaniards, the production of cacao continued for a long time in the hands of the local people, who had to increase production to pay their tribute to the Spaniards and still have enough cacao to sell [3]. 
The first cacao trees grown outside the Americas were established in Africa in 1590 by the Spaniards, in what is now known as Equatorial Guinea, a former Spanish colony [3]. Chocolate consumption expanded from Spain to Italy and later to France and England. Initially, cacao was used to prepare a drink that was consumed in the great aristocratic courts [3].

Cameroon and Ghana were the first cacao growers in mainland Africa, from the late 1870s [3]. Today, the highest production of cacao occurs in the Ivory Coast, Ghana, and Indonesia. It is very interesting that, even though cacao originated in the tropical area of the Americas and the greatest diversity of cacao plants is found there, the main producers of cacao today are the African countries!

\section{IS ALL CACAO THE SAME?}

Cacao originated in the Amazon region of South America. Since its origin, cacao has evolved into different types as it has grown in different geographical populations. Two populations of cacao, with different origins, were initially thought to exist: one from Central America and the other from South America. These two groups were initially recognized as two subspecies, called cacao and sphaerocarpum [4], which were also recognized as the two cacao types most commonly known as Criollo and Forastero, respectively. These subspecies differed not only in where they grew, but also differed in some of their morphological features. The crossing between Criollo and Forastero trees gave rise to a third type, known as Trinitario. Now we know that Criollo, as well as other cacao types, came from an ancestral population in South America, and only spread into Central America when humans migrated there. We also now know that cacao can be divided not only in two or three groups, but into more than 10 different genetic groups [4] (Figure 1).

FLAVOR

PRECURSORS

Some chemical compounds stored inside the seed, such as the carbohydrates and proteins that are transformed during fermentation and play a big role in the final flavor formation of chocolate.

\section{DOES THE FLAVOR DEPEND ON THE CACAO GENOTYPE?}

Chocolate flavor is influenced by different factors: the cacao variety (called the genotype), the growing conditions of the cacao trees, how the beans are treated post-harvest, the fermentation (which will be described below) and drying processes, as well as the processing of the beans into chocolate, in which roasting has a special effect on flavor.

The cacao genotype determines the type and concentration of chemical compounds stored inside the seed, known as flavor precursors, such as the carbohydrates and proteins that are generated during fermentation. The flavor precursors play a big role in the final flavor and aroma of chocolate. The typical chocolate flavor is 
Figure 1

Geographical distribution of cacao groups differing in their genes and morphological features. Cacao originated in the Amazon region of South America, so there is a lot of diversity of cacao plants in that area, making it what is called a diversity hotspot.

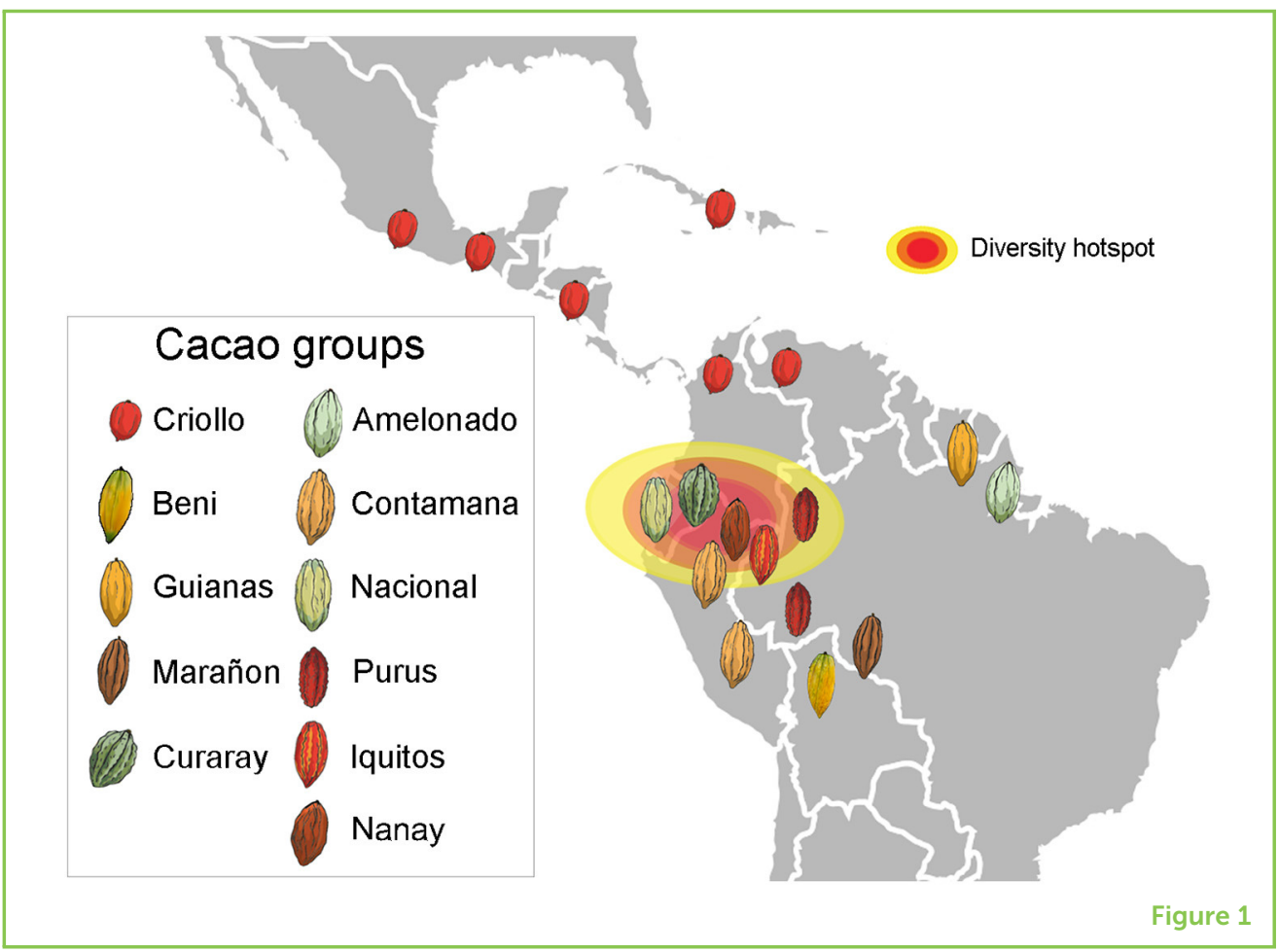

generated once the flavor precursors are transformed, during the roasting of the cacao beans, into key compounds that, also depending on the genotype can have flowery, chocolate, caramel, sweaty, nutty, or fruity notes [5].

\section{FROM FARM TO CHOCOLATE BAR: TRANSFORMATION OF CACAO BEANS INTO CHOCOLATE}

The transformation of cacao beans into chocolate includes several processes, such as fermentation and drying, which are carried out by the producer on the cacao farm after the ripe fruits are harvested. Another process is roasting, which is done during processing to transform cacao beans into chocolate.

\section{Cacao Fermentation}

Cacao bean fermentation is one of the fundamental processes for the generation of the delicious flavor and aroma characteristic of the chocolate [6]. Fermentation of cacao beans is performed using equipment called fermenters. The most common fermenters are wooden boxes that hold from 100 to $400 \mathrm{~kg}$ of beans. Fermentation takes from 4 to 7 days, and the process is performed through the activity of microbes, including yeast and bacteria.

The process starts when the cacao fruits are harvested and opened, and the seeds are placed in the fermenter (Figure 2). Usually, the farmers let the seeds sit without mixing for 24-48 h. At this point, the bacteria and yeast (same as the ones used to make pizza crust 
Figure 2

From trees to

chocolate: how cacao beans are transformed

1. Cacao harvest;

2. Opening of fruits to remove beans;

3. Fermentation;

4. Drying; 5 . Roasting; and 6. Grinding. Illustration by Rafael Yockteng.

\section{CONCHING}

A process in which liquid chocolate goes through intense heating and mixing, which helps to improve the final flavor and to eliminate undesirable flavors, such as acid, bitter, or astringent.

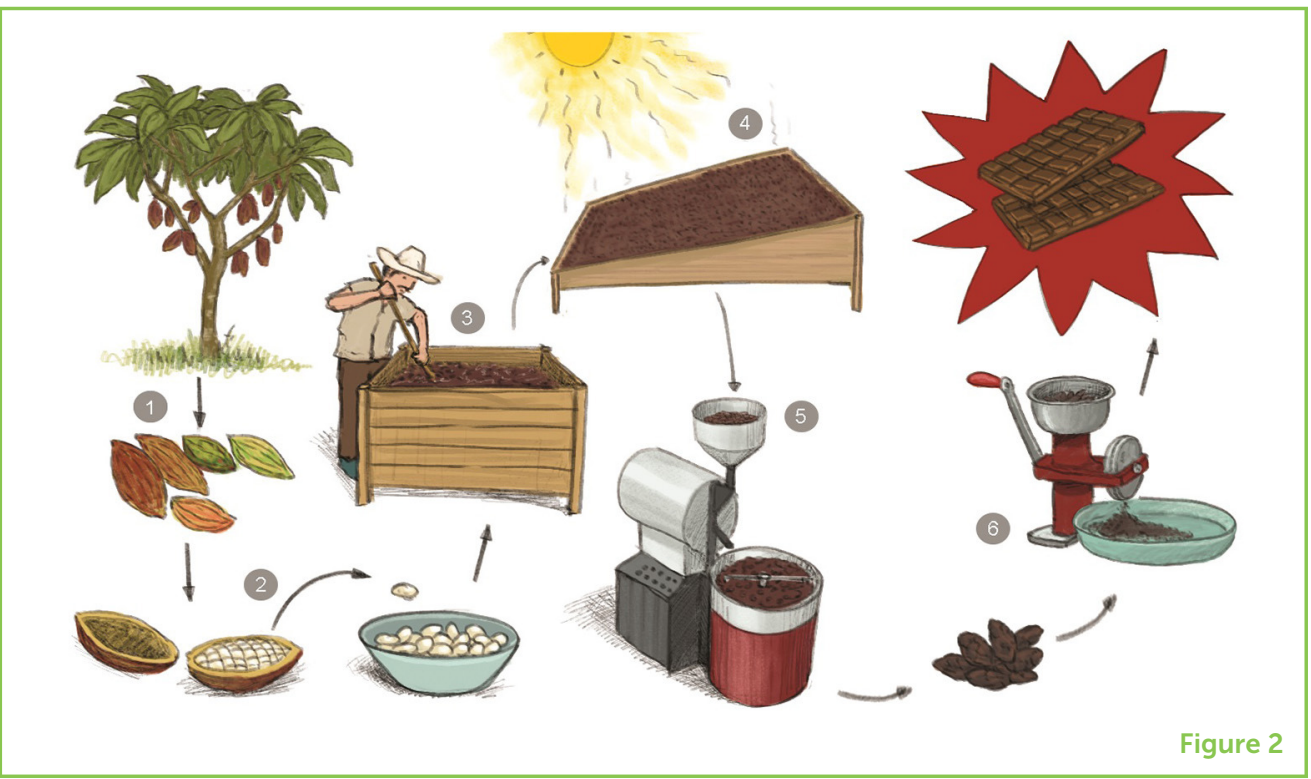

and bread) will start growing on the beans and eating the white pulp surrounding them, transforming it into chemical compounds, such as ethanol and breaking down other compounds that cause undesirable tastes, like bitterness.

Approximately $48 \mathrm{~h}$ after the fermentation has started, the farmer will start mixing the seeds, which introduces oxygen into the fermenter. The introduction of oxygen favors the growth of other groups of bacteria that use ethanol and produce acetic acid. The acetic acid produced by these bacteria causes a chemical reaction that will generate heat, up to $51^{\circ} \mathrm{C}$. This heat will lead to the death of the seed and the formation of the flavor precursors that will later generate the characteristic chocolate flavor. Microbes are therefore fundamental for cacao fermentation and, by controlling the organisms involved in the fermentation, it might be possible in the future to produce distinct and more delicious chocolate flavors!

\section{Cacao Drying}

Once the fermentation process is complete, cacao beans are dried in order to reduce the moisture content to about 7.5\%. Some farmers spread cacao beans out on mats, wooden floors with sliding roofs, trays, or directly on the floor under the sun (Figure 2).

\section{From Cacao Beans Into Chocolate!}

Once the cacao beans have been fermented and dried, they are ready to be transformed into chocolate! This process includes roasting, shelling, grinding, refining, and conching (Figure 2). Of all these steps, roasting is the most important, because this is the process that most influences the quality of the chocolate and forms the chocolate flavor. During roasting, cacao beans are exposed to temperatures from 110 to $160^{\circ} \mathrm{C}$, for times between 5 and $120 \mathrm{~min}$. Due to the 
high temperatures, the flavor precursors, formed during fermentation, react with each other, resulting in new compounds that make the chocolate taste more delicious and acquire its characteristic brown color [5]!

After roasting the cacao beans, the husk that covers them is removed, then they are ground. By a process called refining, the size of the solid particles in the liquid chocolate is reduced to improve the texture, so that when we eat the chocolate it feels softer in our mouths. Another important step in the transformation is conching, a process in which liquid chocolate goes through intense heating and mixing, which helps to improve the final flavor and to eliminate undesirable flavors, such as acid, bitter, or astringent [5].

\section{CONCLUSION}

Chocolate is obtained from the beans of a fruit of a tree called Theobroma cacao, which originated in the Amazon region, explaining why South America has the highest genetic diversity of the species. Theobroma cacao played an important role in the social and political structure of several indigenous civilizations. Spanish colonizers of America took cacao pods to Europe, where cacao became appreciated by social groups with political and economic power. The transformation of cacao beans into chocolate has three important steps: fermentation, drying, and roasting. Chocolate flavor is influenced by several factors: the genotype of the cacao, the growing conditions of the cacao trees, and the post-harvest operations, including fermentation, drying, and the processing of the beans into chocolate, in which roasting has a very important effect on flavor. Cacao is an important source of income for several families in some African and South American countries. Nowadays, the transformation of cacao beans into chocolate represents a very important industry worldwide.

\section{REFERENCES}

1. LeCount, L. J. 2001. Like water for chocolate: feasting and political ritual among the Late Classic Maya at Xunantunich, Belize. Am. Anthropol. 103:935-53. doi: 10.1525/aa.2001.103.4.935

2. Henderson, J. S., Joyce, R. A., Hall, G. R., Hurst, W. J., and McGovern, P. E. 2007 Chemical and archaeological evidence for the earliest cacao beverages. Proc. Natl. Acad. Sci. U.S.A. 104:18937-40. doi: 10.1073/pnas.0708815104

3. Nunn, N., and Qian, N. 2010. The Columbian exchange: a history of disease, food, and ideas. J. Econ. Perspect. 24:163-88. doi: 10.1257/jep.24.2.163

4. Motamayor, J. C., Lachenaud, P., Wallace, J., Loor, R., Kuhn, D. N., Brown, S., et al. 2008. Geographic and genetic population differentiation of the Amazonian chocolate tree (Theobroma cacao L). PLOS ONE 3:e3311. doi: 10.1371/journal.pone.0003311

5. Santander, M., Rodríguez, J., Vaillant, F., and Escobar, S. 2019. An overview of the physical and biochemical transformation of cocoa seeds to beans and to 
chocolate: flavor formation. Crit. Rev. Food Sci. Nutr. 1-21. doi: $10.1080 / 10408398.2019 .1581726$

6. Papalexandratou, Z., Lefeber, T., Bahrim, B., Lee, O. S., Daniel, H. M., and De Vuyst, L. 2013. Hanseniaspora opuntiae, Saccharomyces cerevisiae, Lactobacillus fermentum, and Acetobacter pasteurianus predominate during well-performed Malaysian cocoa bean box fermentations, underlining the importance of these microbial species for a successful cocoa. Food Microbiol. 35:73-85. doi: 10.1016/j.fm.2013.02.015

SUBMITTED: 02 July 2019; ACCEPTED: 03 March 2020; PUBLISHED ONLINE: 24 March 2020.

EDITED BY: Vincenzo Naddeo, University of Salerno, Italy

CITATION: Rodriguez-Medina C, Escobar S, Caro-Quintero A and Yockteng R (2020) A Delicious Story Made of Chocolate. Front. Young Minds 8:33. doi: 10.3389/ frym.2020.00033

CONFLICT OF INTEREST: The authors declare that the research was conducted in the absence of any commercial or financial relationships that could be construed as a potential conflict of interest.

COPYRIGHT @ 2020 Rodriguez-Medina, Escobar, Caro-Quintero and Yockteng. This is an open-access article distributed under the terms of the Creative Commons Attribution License (CC BY). The use, distribution or reproduction in other forums is permitted, provided the original author(s) and the copyright owner(s) are credited and that the original publication in this journal is cited, in accordance with accepted academic practice. No use, distribution or reproduction is permitted which does not comply with these terms.
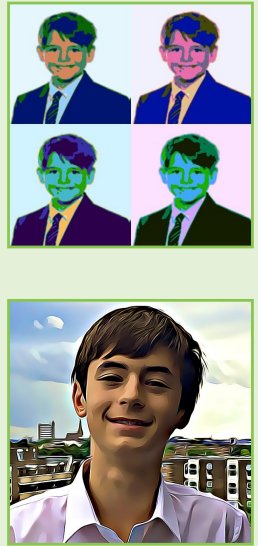

\section{OLI, AGE: 13}

Oli is a keen guitar player who enjoys speaking Mandarin and playing computer games.

\section{SHEENA, AGE: 12}

$\mathrm{Hi}$, I am Sheena I go to Maiden Erlegh School. I enjoy science and love when I do science experiments. I really enjoy chemistry and mixing new things to cause reactions that I have never seen before. I love trying out new things and discovering things that other people have never done before. 


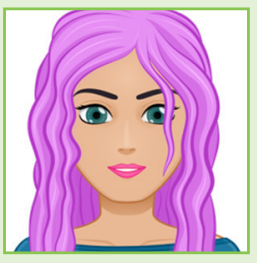

\section{SHIRIN, AGE: 14}

$\mathrm{Hi}$, I am Shirin and I am in year 10 and I go to Maiden Erlegh School. I am happy to have helped in reviewing this article and it is been a fun experience combining my Science and English skills for this, I really enjoyed this and recommend it to anyone with similar interests to me!
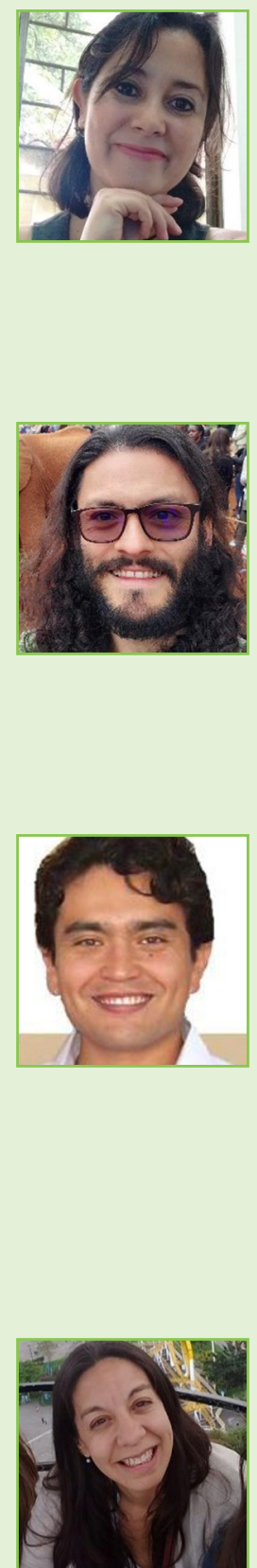

\section{AUTHORS}

\section{CAREN RODRIGUEZ-MEDINA}

Caren Rodriguez-Medina is a Ph.D. researcher from Agrosavia, Colombia, since December 2014. She obtained her Ph.D. from the University of Western Australia in Perth, Australia. After obtaining her Ph.D., she worked as a post-doctoral researcher at the French National Institute for Agricultural Research, INRA, in Colmar, France, in a project studying plant-pathogen interactions. Caren's current research at Agrosavia focuses on Theobroma cacao genetics and breeding to increase productivity and disease resistance. * ${ }^{*}$ drodriguez@agrosavia.co

\section{SEBASTIAN ESCOBAR}

Sebastian Escobar works as Ph.D. researcher in Palmira Research Center which belongs to the Colombian Agricultural corporation-Agrosavia in Bogotá, Colombia. He received his Master's degree in Industrial Process Engineering. He got a Ph.D. in Chemical Engineering. He currently works studying the processes to transform cacao during the post-harvest stage, to produce fine flavor cocoa beans to obtain a very good chocolate bar. Also, he has worked in drying technologies for the food sector.

\section{ALEJANDRO CARO-QUINTERO}

Alejandro Caro is a Ph.D. researcher at Agrosavia, Colombia. He holds a B.Sc. in microbiology from Universidad de los Andes, with a Master's degree and a Ph.D. from the Georgia Institute of Technology. His Ph.D. focused on the DNA information to elucidate how microbes evolved and what capabilities do they have. After his Ph.D., he worked as a post-doctoral researcher at the University of Texas. His research at Agrosavia focuses on the use of high-throughput sequencing tools to improve the production and quality of agricultural and livestock systems. In 2018, he was nominated as the young ambassador of the American Society for Microbiology for Colombia.

\section{ROXANA YOCKTENG}

Roxana Yockteng obtained her Ph.D. from the University Paris XI-Sud in Orsay, France. Her research has been dedicated to the study of the evolution of plants. Since 2005, she is Associate Professor at the National Museum of Natural History in Paris, her research focused on the evolution of interaction between plants and organisms. She also worked as a researcher at the University of California at Berkeley studying the evolution of plant development. Since October 2014, she is a researcher at Agrosavia, Colombia, where she studies the genetics implicated in disease resistance and cadmium absorption in cacao crops. 